\title{
The Reform and Innovation of the Applied Talent Cultivation Mode in Software Engineering
}

\author{
LI Jun-shan, LI Jian-jun \\ The institute of information science \& technology, South China Business College Guangdong University of Foreign Studies, \\ Guangzhou 510545, China
}

\begin{abstract}
The paper is based on the theoretical research and practical experience of the reform and innovation of the applied talents training model of the software engineering major in college. First, we introduced our college's understanding of the knowledge and capability framework of applied talents in software engineering. Second, it introduced the positioning and education concept of the software engineering professional application talent training goal. Then, the paper introduces the reform ideas and reform practices of the applied talents training model for software engineering in our college. Finally, the paper introduces the academic value and innovation of the innovative research on the application-oriented personnel training model for software engineering in our college. The preliminary teaching practice shows that the college's innovative talent training model for software engineering specialties is in line with the basic qualities of software engineering professionals and the need for capacity development. It is hoped that our college's approach can provide inspiration to the reform of the applied talents training model in other universities.
\end{abstract}

Keywords-Software Engineering; Applied Talents; Training Models; Knowledge and Ability Architecture; Educational Concepts; Reform Practices

\section{INTRODUCTION}

With the rapid development of Internet technology and the continuous development of China's software industry, the demand for application-oriented software talents is increasing. With the acceleration of the construction of Guangdong, Hong Kong, and Macao Bay Area, the software professionals will serve the economic and social. The ability to drive innovation has put forward higher requirements, all of which put forward new and higher requirements for the construction of software engineering majors in undergraduate colleges in Guangdong and the transition to application technology.

Based on the analysis and understanding of the author's training of applied talents promoted by the country, this article introduces the structure and knowledge of the applied talents of the software engineering major in the reform and innovation practice of the software engineering professional talents training model. Cognition and positioning of the training target for applied talents in software engineering. Finally, the author introduced the reform ideas, reform practices and reform effectiveness of the application-oriented personnel training model for software engineering majors.

\section{KNOWLEDGE AND ABILITY STRUCTURE OF APPLIED TALENTS IN SOFTWARE ENGINEERING}

Focusing on the theoretical research and teaching practice requirements for the innovative experimental area construction of the software engineering professional applied talents training model, the social perception of the applied talents training project team members of the "Software Engineering Professional Application Talents Training Model Innovation Experimental Area" team members and Guangdong The province's information industry technology field has conducted a comparatively comprehensive survey on the knowledge structure and capability requirements of undergraduate software engineering majors[1-2], and has a clearer understanding of the law of talent cultivation in software engineering undergraduate majors and their technical fields. It is believed that the cultivation of applied talents in software engineering must firstly understand the knowledge and ability needs of applied talents, and then must build a knowledge and ability framework (cultivating model) for training applied talents, and secondly, establish knowledge and ability to transform The comprehensive training mechanism and supporting conditions must be followed by the construction of a teacher team that can complete the training of the training mode at a high level and lead the students to realize the transformation of knowledge into capabilities. Therefore, in terms of the training of applied talents in software engineering, we must first of all clarify and solve the following problems:

(1) Knowledge structure and capability requirements of applied talents. In other words, it is necessary to find out which application-type knowledge is needed in its professional and technical fields and what comprehensive practice, comprehensive analysis and comprehensive design capabilities are required.

(2) Construction of knowledge and ability of applied talents That is, according to the applied knowledge and ability, it is necessary to construct a reasonable applied talent training model or knowledge ability framework[3]; and in the formulation of the application talent training program, we must take into account solid basic theoretical knowledge (in which courses, The curriculum should include what content systems, the same below), moderate professional widening and interdisciplinary knowledge, knowledge for comprehensive analysis and comprehensive design ability training, and most of them are not good for "comprehensive analysis and 
comprehensive design "Capacity-building" knowledge or measures are not planned and implemented well.

(3) How to build a comprehensive training mechanism and supporting conditions for the transformation of knowledge into capabilities. That is, the actual implementation of the relevant teaching and practice links in the implementation process of application-oriented personnel training. The current problems are many of the teaching materials, teaching methods, comprehensive practical conditions of the courses combined with the comprehensive analysis and comprehensive design ability training, the organization and implementation of comprehensive practice, and the level and ability of teachers who undertake this part of the teaching work. All or none of the items are not up to standard or have not been actually implemented according to the corresponding requirements.

(4) High-level completion of the teaching of training mode and the construction of a faculty team that leads students to realize the transformation of knowledge into capabilities. That is, it is necessary to build a team of teachers with high theoretical level, flexible and diverse teaching methods, comprehensive practice and comprehensive analysis, and comprehensive design ability.

At the same time, the project team also realized in particular that the knowledge and capability framework of applied talents in software engineering requires close coupling of theory and practice, theoretical knowledge and comprehensive design capabilities. The theoretical knowledge of light cannot be programmed and software design cannot be called software talent. Without software design and programming capabilities, it is impossible to accumulate practical experience and it is impossible to develop a high-level software system with independent intellectual property rights. Therefore, the software professionals themselves have applied and practical characteristics. The nation's applied talent training strategy and the software engineering professional training structure are essentially a high degree of unity. Therefore, the establishment of practice teaching system and training conditions for practical training around the practice, design, and innovation ability training is the key link in the construction of an innovative experimental area for the applied talents training model of software engineering.

\section{THE ORIENTATION AND EDUCATIONAL CONCEPT OF TRAINING TARGET FOR APPLIED TALENTS IN SOFTWARE ENGINEERING}

\section{A. The Goal of Training Softwaree Engineering Professionals}

On the basis of summarizing the teaching practice experience and further investigation and study of project team members, the training objectives of the software engineering major determined by the project team are: to cultivate a good information science literacy and to systematically master the basic theory and foundation of computer software and application. Knowledge and basic skills; has the ability to research, develop and maintain computer software systems and related technologies in the field of computer software technology; has strong English application ability, innovative spirit, comprehensive practical ability and teamwork spirit; can better To adapt to the needs of the region's economic development and social science and technology development, application-oriented professionals with full development of morality, intelligence, and physical development.

This training goal emphasizes "can better adapt to the needs of economic construction and social science and technology development in the region", and makes "application-oriented" more targeted and positioned; "has strong English application ability" and so on, combined with our school The orientation and characteristics of "Foreign Language + Professional" education, and the orientation and understanding of the related talent training objectives in the training objectives are in line with the knowledge characteristics of this type of specialty and the comprehensive quality requirements of undergraduate applied talents.

\section{B. Education Concept of Software Engineering Talent Cultivation}

The application and practical characteristics of software professionals determine that the construction of the profession should focus on the needs of local economic development, and the cultivated talents should be consistent with the types of applied talents required by the regional information industry and economic development. Based on this understanding, during the construction of an innovative experimental area for the application-oriented talents training mode of software engineering, the project team places special emphasis on quality education (knowledge, ability and quality interact and develop harmoniously, and strengthen ability and quality as goals) and creativity (entrepreneurship) Combine and innovate the combination and integration of the two concepts of education[4], carry out personnel training model innovation, and adapt to the comprehensive curriculum content reforms and supporting practice training base construction; with special emphasis on building a "applicable talent". To cultivate a practical knowledge-training, strong-ability, and high-quality talent-training system framework, and in the construction of a curriculum group that is closely coupled with characteristic professional basic knowledge and comprehensive practice design capabilities, relevant grasping and construction measures should be operable. 


\section{REFORM AND PRACTICE OF TRAINING MODE OF APPLIED TALENTS IN SOFTWARE ENGINEERING}

\section{A. Reform Ideas of Training Mode of Applied Talents in Software Engineering}

Based on the training objectives of software engineering professionals in Section 3.1, we have positioned the train of thought for the reform of the talent cultivation model as follows: Taking the development needs of the economic construction in Guangdong as a leader, taking the knowledge and capability needs of the Guangdong information industry and information technology professionals as the traction, and taking the information engineering college as a software engineering major. Students are the mainstay, relying on the Subject Experiment Center, off-campus practice training and teaching base, and "customized" top software talent training college as the backing, and "application-oriented talents" training as the focal point, with professional basic knowledge, comprehensive practice and comprehensive design ability. Cultivate a tightly coupled curriculum group construction as a starting point [5,6], rationally determine the depth of professional knowledge, appropriately widen the scope of interdisciplinary knowledge, effectively integrate theoretical and practical teaching content, comprehensively improve experimental teaching conditions, and constantly innovate teaching and talent cultivation systems, Gradually building an undergraduate applied talents training system focusing on cultivating innovation capabilities, professional basic knowledge, practical ability, and high overall quality.

\section{B. Reform Practice of Application-oriented Talents Training Mode in Software Engineering}

The research and practice of the innovative experimental zone project around the application-oriented personnel training model in our school has carried out the reform and practical exploration of the software engineering professional talent model [7].

The first type of employment for software engineering students is software programming. In addition to requiring students to master the operation and application of commonly used software, students are more familiar with mathematical modeling, algorithm design, logical thinking, and computational theory. And so on have higher requirements. To this end, our school has improved students' mathematics modeling and algorithm building capabilities by adding calculation methods, algorithm analysis and design, artificial intelligence and other courses.

For the current independent college-type college students, most of the courses on the combination of theory and practice can only achieve the "basic understanding" and difficult to achieve the application-oriented transition. Therefore, from the two perspectives of mastering knowledge and cultivating ability, our school has constructed four closely related curriculum groups [5-6]: (1) programming and development technology curriculum group is composed of "Program design basis" and "Program Design Comprehensive Design and Practice". (2) Database application system design technology curriculum group composed of "Database Principles and Applications" and "Database Application System Comprehensive Design and Practice". (3) The software engineering technology curriculum group composed of "software engineering" and "software engineering comprehensive practice". (4)The mobile software development technology curriculum group composed of "WEB application development", "mobile application development technology" and "mobile platform comprehensive development practice" guarantees the transformation of students' knowledge into capabilities from the curriculum system and practical teaching system.

In order to teach students to use engineering concepts, principles, techniques, and methods to develop software [8], students are then taught how to analyze, design, and integrate projects that have different development contexts. Through the analysis and design of the "University Teaching Information Management Database Application System" in the database course, the school runs through the case teaching of the entire course, highlighting the analysis, design and synthesis process of typical software design cases, and training and improving students' problem solving. The ability to analyze problems and analyze and design software using engineering methods has achieved good teaching results in cultivating students' application-type capabilities.

In order to strengthen students' practical ability and improve their ability to connect with business needs, the school has signed agreements with more than a dozen companies and science and technology companies to build internships and practical training bases. Each semester is based on the curriculum characteristics of students of all grades. Through practical training weeks, we will carry out concentrated and practical training in practical and design courses. In particular, through the hiring of technical personnel from related companies to carry out a week of project development training for students in third and fourth grade, not only enables students to initially understand the basic process of actual project development by technology companies, but also enables students to promote their own applications. The ability of the type has confidence, which also enables the trained software engineering professionals to adapt to the needs of the development of Guangdong's information technology and information industry. 


\section{THE ACADEMIC VALUE AND INNOVATION OF RESEARCH ON APPLICATION-ORIENTED TALENTS TRAINING MODE}

\section{A. The Main Academic Value of the Research Model of Applied Talent Cultivation}

(1) What is considered as an applied talent? This is the core issue to solve the "transition to application". Through the research on the basic knowledge, applied knowledge, and comprehensive qualities of applied talents in software engineering, our school solves the theoretical and practical problems in the transition from computer science to application.

(2) Achieving the "transformation from regular undergraduate colleges to applied ones" must first achieve the transition from a talented person training program in each of the universities to an applied one, and realize the guarantee conditions for the curriculum system and laboratory construction that constitute the training program. Applicationoriented, it is the key to achieving "the transformation of ordinary undergraduate universities to application-oriented". The research on how to build the training model for applied talents in software engineering majors carried out by our university has provided practical experience for realizing the transition from "computerized" to "applied".

(3) Our school focuses on the construction of a closely coupled curriculum of "theory, knowledge, and ability" related to the cultivation of applied talents. It involves the understanding and understanding of the characteristics of different levels and different types of curriculum groups. It is in itself a question of academic value.

\section{B. The Innovation of the Applied Talent Cultivation Mode Constructed}

(1) For the software engineering profession, a number of curriculum groups are established to support the development of the professional knowledge structure and application capabilities (the curriculum in each curriculum group is divided into theoretical courses and comprehensive design and practice-based capacity-building courses), and The comprehensive design and practical ability-building curriculum constructs the experimental practice conditions construction plan and carries out the corresponding research ideas for the construction of the teaching staff, and has grasped the key to enhance the ability and application-oriented in the applicationoriented personnel training process, and is innovative and feasible.

(2) The research content involves how to achieve the tight coupling of "theory, knowledge, and ability", involving the conversion of knowledge to ability, and the relationship between theoretical courses and ability-based training courses and their contribution to the cultivation of applied talents. The research is basic and certain theoretical.
(3) Studying the application and innovation ability of software engineering undergraduate majors in "independent college" type colleges and universities that are transformed into applied ones, and is in line with the "National Major Strategy" initiative of the people's innovation and entrepreneurship, and it is advanced. Studying and Solving the Problems in Applying the Transition to Higher Education How to develop applied and compound talents that meet the requirements of regional economic development is an urgent issue to be solved in the current development of higher education. Researching and constructing a regional-oriented application-oriented talent training model is consistent with the "Guiding Opinions on Guiding Some Local Undergraduate Universities in Transition to Application-type" issued by many ministries and commissions such as the Ministry of Education, and it is advancing with the times.

\section{CONCLUSION}

The reform and innovation of the application-oriented personnel training model for software engineering is the key to improving the innovation and entrepreneurship ability of this professional college student. In the reform and innovation of the software engineering professional application talent training model, the school has demonstrated the knowledge of the cultivation model for the theoretical knowledge training system, practical ability training system and innovation and entrepreneurship training system constructed by the software engineering major. The capability framework is in line with the basic quality requirements of software engineering professionals; the practical teaching system of the training model is in line with the ability of software engineering professionals to develop their capabilities. It is hoped that our approach will improve the quality of application-oriented personnel training for software engineering majors in our university, and at the same time, it will provide inspiration for the reform of the applied talents training model in related institutions.

\section{ACKNOWLEDGMENT}

Supported by Teaching Quality Improvement Project and Teaching Reform Project for Guangdong Undergraduate Universities (No.296); Educational Innovation Project of Educational Department of Guangdong (Education Research) (No.2017GXJK243) 


\section{REFERENCES}

[1] SUN Guang-dong. The Construction and Practice of Innovation Experiment Zone for Electric Information Personnel Training Model with Local Specialties [J]. Education teaching Forum, 2016, (5):281282. (In Chinese)

[2] FEI Xuan, YU Ren-ping, ZHAO Yu-juan, etal. Research on Specialty Construction of Software Engineering for Professional Certification[J]. Computer Engineering \& Software, 2016, 37(10):7-9. (In Chinese)

[3] JIANG Hui, HUANG Xiao-lin, DAI Na-xin, etal. Experiments construction of civil engineering mechanics course oriented knowledgeability integration cultivating $[\mathrm{J}]$. Journal of Architectural Education in Institutions of Higher Learning, 2016, 25(6):139-142. (In Chinese)

[4] Educational idea. https://baike.so.com/doc/5410161-5648236.html. (In Chinese)

[5] Li Hao. Construction of Curriculum Group of Information and Computing Science based on the Cultivation of Professional Core Competence[J]. China Computer \& Communication, 2017, (5):236-237. (In Chinese)

[6] SHEN Hai-bo, ZHU Xiong-yong, ZHOU Ru-qi, etal. Construction and Practice of Software Engineering Based on Characteristic Curriculum Group[J]. Computer Education, 2017, (12):141-143. (In Chinese)

[7] YOU Chui-Jie, QIU Jin-ming, LIU Chi-biao. "Five-in-one" IT-type application of technology-based personnel training model reform[J]. Computer Education, 2017, (10):104-107. (In Chinese)

[8] TIAN Bao-jun. Research on Case Teaching Method of Software Engineering Course[J]. Journal of InnerMongolia Normal University(Educational Science), 2008, 21(1):103-105. (In Chinese) 